IRSTI 13.07.77

\author{
"Abikenov Zh.O., Gabitov T.H. \\ Al-Farabi Kazakh National University, Kazakhstan, Almaty \\ *e-mail: abikenovkz@gmail.com
}

\title{
METHODOLOGICAL PRINCIPLES OF THE SEMIOTIC APPROACH IN THE STUDY OF CULTURAL STUDIES
}

This article explains the methodological foundations of the science of semiotics which are widely used in modern cultural research science and in the study of important signs of today's society. In the methodological basis of the study, special attention was paid to the fundamentals of the analysis of semiotics, a methodological analysis was made to theoretical areas in which it was taken as an object of symbolic analysis of the study by Ferdinand de Saussure, C. Pierce, J. Lotman. In the study of the methods of the science of semiotics, a review has been made of many theoretical studies which gives us the opportunity to explore the main world outlook system in a semiotic way.

Signs surround a person from all sides: in art, nature, everyday life, wherever there is a problem of communication or perception. Therefore, the special attention of scientists F de Saussure, C. Pierce, Y. Lotman is attracted to the methods of semiotic research based on the achievements of semiotics, which is the basis for studying symbols, constructs, concepts, etc. The semiotic approach is focused primarily on the analysis of the material in the system of terms and concepts of semiotics. Thus, penetrating into the sphere of various methodological approaches, the semiotic aspect expands both the capabilities of the methodology as a whole and its own research strategies.

Key words: culture, symbol, semiotics, approach, theory, methodology.

\author{
*Әбікенов Ж.О., Ғабитов Т.Х. \\ Әл-Фараби атындағы Қазақ, ұлттық университеті, Қазақстан, Алматы қ. \\ *e-mail: abikenovkz@gmail.com
}

\section{Мәдени зерттеуді оқытудағы семиотикалық тәсілдердің методологиялық принциптері}

Бұл мақалада қазіргі мәдени зерттеулер ғылымында кең қолданыста болып жүрген және бүгінгі қоғамдағы белгілердің маңыздылығын зерттеуге қолданылып жүрген семиотика ғылымының әдістемелік негіздеріне түсіндірме беріледі. Семиотикалық талдау негіздеріне басты назар аударылып, зерттеудің әдістемелік негізінде Фердинанд де Соссюрдің, Ч. Пирс, Ю. Аотманның еңбектері рәміздік талдау объектісі ретінде алынып, олардың теориялық бағыттарына әдістемелік талдау жасалынды. Семиотика ғылымының әдістерін зерттеу барысында көптеген теориялық ізденістерге шолу жаса^ды, бұл бізге дүниетанымдық түсініктерінің негізгі жүйесін семиотикалық тәсілде зерттеуге мүмкіндік берді.

Жалпы белгілер адамға әр тараптан өнерде, табиғатта, күнделікті өмірде, қарым-қатынас мәселелерінде немесе оны қабылдауда болсын, барлық тұрғыла әсер етеді. Сондықтан да, Фердинанд де Соссюр, Ч. Пирс, Ю. Аотман сияқты ғалымдар негізгі базалық рәміздік құрылымдағы тұжырым болып табылатын семиотика ғылымының негізгі жетістіктерін бұрын, семиотикалық, зерттеу әдістеріне ерекше назар аударды. Бұл тұрғыда семиотикалық тәсілдер ең алдымен, семиотикалық терминдер мен түсініктер жүйесіндегі материа^ды та^дауға бағытталады. Осылайша, әртүрлі әдіснамалық, тәсілдер саласына еніп, семиотикалық, аспект бүкіл әдіснамалық, мүмкіндіктері мен өздерінің жеке зерттеу бағдарламасын кеңейтеді.

Түйін сөздер: мәдениет, рәміз, семиотика, тәсіл, теория, әдістеме. 


\author{
"Абикенов Ж.О., Габитов Т.Х. \\ Казахский национальный университет им. аль-Фараби, Казахстан, г. Алматы, *e-mail: abikenovkz@gmail.com
}

\title{
Методологические принципы семиотического подхода в изучении культурологии
}

В этой статье объясняются методологические основы науки семиотики, которые широко используются в современной культурной исследовательской науке и в исследовании важных знаков сегодняшнего общества. В методологической основе исследования особое внимание уделено основам анализа семиотики, слелан методологический анализ теоретических направлений, в котором взят как объект символического анализа исследования Фердинанд де Соссюра, Ч. Пирса, Ю. Аотмана. При изучении методов науки семиотики сделан обзор на многие теоретические исследования, которые дают нам возможность исследовать семиотическим способом основную систему мировоззрения.

Знаки окружают человека со всех сторон: в искусстве, природе, повседневной жизни везде, гАе есть проблема коммуникации или восприятия. Поэтому особое внимание ученых $Ф$ де Соссюра, Ч. Пирса, Ю. Аотмана привлекают методы семиотических исследований, основанных на достижениях семиотики, являющейся базой Аля изучения символов, конструктов, концептов и др. Семиотический подход ориентирован, прежде всего, на анализ материала в системе терминов и понятий семиотики. Таким образом, проникая в сферу различных методологических подходов, семиотический аспект расширяет как возможности методологии в целом, так и собственные исследовательские стратегии.

Ключевые слова: культура, символ, семиотика, подхоА, теория, методология.

\section{Introduction}

The term "culture" is, of course, a contested term with multiple meanings in various contexts and discourses. In the context of semiotics, culture can be viewed as the sum of rule-governed, shared, learned and learnable, transmittable, symbolic activity used by a group in any given place and time. "Culture is the generator of structuredness the nonhereditary memory of the community". Meanings, values, significance circulate in second-order languages that use both ordinary language and other sign-systems like visual images, mass media, and information technology. All these ways of transmitting shared and stored meanings involve a mediated content. To be in a culture means to be in preexisting but constantly changing sign-systems.

In the "Cultural Studies" model, "culture" is a field of conflicting and competing forces resulting from structured asymmetries in power, capital, and value.

Cultural Studies as an academic field has been accused of dematerializing or leveling media content in order to objectify ideological and political messages for analysis. The approach is often further characterized as an "effects" model of analysis that focuses on capitalist and corporate mechanisms of control and usually omits the agency and activity of individuals, groups, and subcultures who are the receivers and users of media.

Semiotics is a discipline, in which culture, society and natural phenomena are explored as signs. The fundamental question in semiotics is how meanings are formed. Semiotic research approaches sign as existing in various forms: pictures, words, letters, objects, natural objects, gestures, phenomena and actions. Semiotics explores the content of signs, their use and the formation of meanings of signs at both the level of a single sign and the broader systems and structures formed by signs. Semiotics as a discipline includes several distinguished traditions, each using its own terminology and concepts.

The hypothesesis of the research was that in order was that in order to interpret these visual sings correctly, children have to reveal to semiotic system they are part of and the, discover the semiotic principles behind the formation of every sign or group of signs. (Eero Tarasti, 2009)

If you use semiotic analysis your aims are to analyze, understand and interpret signs, the meanings of signs, and the interaction of signs and sign systems. Semiotic analysis views the sign and use of signs as a part of a sign system. A sign system directs the use of the sign and thus, the system always has an effect on the contents of individual signs. A sign is never independent of the meanings and use of other signs. Semiotic analysis uses both qualitative and interpretative content analysis involving semiotic concepts and terms.

\section{Research methods}

The methodology of this work includes such theoretical approaches as the system-structural method, the interdisciplinary method, the source study method. 


\section{The main theory}

Semiotics definition could become very difficult for people but semiotics could be anywhere. The shortest definition is that it is the study of signs but what does it mean by sign? The kinds of signs that are likely to spring immediately to mind are those which routinely refer to as "signs" in everyday life, such as road signs and zodiacal signs. Moreover it is more than that. Our environment consists of peculiar signs: A natural phenomena, computer programs, painting, music and, certainly, languages, both artificial and natural. Any person lives in the world of signs, uses signs and in certain situations is a sign himself. A human gait, peculiarities of his/ her figure, a voice timbre, and a hairdo is incomplete character set by which are recognized the person as known.

Semiotics has been applied to film, theatre, medicine, architecture, zoology, and a host of other areas that involve or are concerned with communication and the transfer of information. In fact, some scientists suggest that everything can be analyzed semiotically; they see semiotics as the queen of the interpretive sciences, the key that unlocks the meaning of all things great and small (Melahat Arıklı, 2016).

Semiotics is important because it can help us not to take 'reality' for granted as something having a purely objective existence which is independent of human interpretation. It teaches us that reality is a system of signs. Studying semiotics can assist us to become more aware of reality as a construction and of the roles played by ourselves and others in constructing it. Itcan helpus to realize thatinformation or meaning is not contained in the world or in books, computers or audio-visual media. Meaning is not 'transmitted' to us-we actively create it according to a complex interplay of codes or conventions of which we are normally unaware. Becoming aware of such codes is both inherently fascinating and intellectually empowering. We learn from semiotics that we live in a world of signs and we have no way of understanding anything except through signs and the codes into which they are organized. Through the study of semiotics we become aware that these signs and codes are normally transparent and disguise our task in reading them. Living in a world of increasingly visual signs, we need to learn that even the most realistic signs are not what they appear to be. By making more explicit the codes by which signs are interpreted we may perform the valuable semiotic function of 'denaturalizing' signs. In defining realities signs serve ideological functions.
Deconstructing and contesting the realities of signs can reveal whose realities are privileged and whose are suppressed. The study of signs is the study of the construction and maintenance of reality. To decline such a study is to leave to others the control of the world of meanings which we inhabit (Electronic resource http://visual-memory.co.uk/daniel/ Documents/S4B/sem01.html).

Methodological principles of cultural semiotic approach were systematized-understanding of culture as a structure consisting of a series of symbolic systems and cultural texts;-principle of symbol creation, actualized in artistic dialogism;representative nature of culture and symbolic interpretation of the signs of culture;-the concept of "value" as a key one in the conception of semantic philosophy of art. Consideration of cultural-semiotic approach in correlation with constructivism ideas made it possible to complement the methodological principles of the approach in regard to understanding the nature of art. Art is understood as a culturalsemiotic construct that generates social meanings in individual and collective consciousness. As a secondary constructing system art, in its cultural and semiotic forms, embodies already existing and functioning primary constructs that embody ethnical and cultural values. Art has a socio cultural dynamics that allows humans to verify ideas about the world and construct their own picture of the world on a subconscious level.

Semiotics is not widely institutionalized as an academic discipline. It is a field of study involving many different theoretical stances and methodological tools. One of the broadest definitions is that of Umberto Eco, who states that 'semiotics is concerned with everything that can be taken as a sign'. Semiotics involves the study not only of what we refer to as signs in everyday speech, but of anything which 'stands for' something else. In a semiotic sense, signs take the form of words, images, sounds, gestures and objects. Whilst for the linguist Saussure, semiology was a science which studies the role of signs as part of social life, for the philosopher Charles Peirce semiotic was the formal doctrine of signs which was closely related to Logic. For him, a sign is something which stands to somebody for something in some respect or capacity. He declared that every thought is a sign. Contemporary semioticians study signs not in isolation but as part of semiotic sign systems. They study how meaningsare made: as such, being concerned not only with communication but also with the construction and maintenance of reality. For C.W. Morris, semiotics embraced semantics, along with the other traditional 
branches of linguistics: semantics: the relationship of signs to what they stand for, syntactics: the formal or structural relations between signs, pragmatics: the relation of signs to interpreters (Electronic resource// http://visual-memory.co.uk/daniel/Documents/S4B/ sem01.html).

Ferdinand de Saussure and Charles Sanders Peirce, Lotman are considered the fathers of semiotics. Therefore, here culture is understood as a system of symbols or meaningful signs. Because the main sign system is the linguistic system, the field is usually referred to as semiotics of culture and language. Under this field of study symbols are analyzed and categorized in certain class within the hierarchal system. With postmodernity, metanarratives are no longer as pervasive and thus categorizing these symbols in this postmodern age is more difficult and rather critical.

From the point of view of semiotics, any action that can be related to signs can also be said to be descriptive. Semiotics deals with descriptions, and any descriptive action can be the object of semiotic study (Eero Tarasti, 2004).

\section{Pierce semiotic theory}

American scholar Charles S. Peirce and Swiss linguist Ferdinand de Saussure are both regarded as the founder of modern semiotics. Peirce's semiotics which is different from Saussure's dyadic semiotics is a kind of triadic semiotics. He defines a sign as a triad made of three indecomposable elements: a representamen, an object, and an interpretant (Chandler, 2002).

According to Peirce, a sign is something, which stands to somebody for something in some respect or capacity. It addresses somebody, that is, creates in the mind of that person an equivalent sign, or perhaps a more developed sign. That sign which it creates I call the interpretant of the first sign. The sign stands for something, its object. It stands for that object, not in all respects, but in reference to a sort of idea, which I have sometimes called the ground of the representamen (Peirce, 1960).

The interaction between the representamen, the object and the interpretant is referred to by Peirce as semiosis. The relationship between the three elements can be seen in the following figure. By semiosis, I mean, on the contrary, an action, or influence, which is, or involves, a cooperation of three subjects such as a sign, its object, and its interpretant, this tri-relative influence not being in any way resolvable into actions between pairs (Peirce, 1998).
There are signs around us, and everything conveying meanings can be seen as a sign from the perspective of semiotics. Most signs have their specific meanings, and they can explain different cultures and connotations more vividly. With the rapid development of world economy and policy, the communications between different cultures become increasingly frequent. It is important to make a comfortable communication. To avoid misunderstanding, it is necessary to understand different cultures (Shirong Zhang, Fan Yang, 2012). Peirce's model of signs is built on his theory of reality. Any sign consists of three interrelated components: The sign, the object, and the interpretant. The sign is that particular physical or conceptual entity that will serve as the "home" of the sign relation. The thing that it stands for or represents is its object. Finally, there will be a consequence of the object being represented by the sign in question that will be different from the manifestation of the object in and of itself, and that mediated consequence is what Peirce called the interpretant. An interpretation of signs as signs for particular objects is an obvious example of an interpretant, but the concept of interpretant is much broader than interpretation (Melahat Arıkl1, 2016).

Peirce offered another model comprising a representamen, an interpretant, and an object. According to Peirce, a sign has three modes: icon, index, and symbol. Saussure's system is generally appropriate to language and texts, whereas Peirce's model has a wide application, including different forms of media and visual arts. The semiotic theories of Roland Barthes, Algirdas Greimas, and Umberto Eco extended these ideas to all types of messages, including architectural works (Nelly Shafik Ramzy, 2014).

\section{Saussure semiotic theory}

The origins of semiology are located with the work of the French linguistic, his study, Course in General Linguistic, set the agenda for the ways in which signs are examined, Saussure analyzed the sign into its two basic components: A sound component which he named the signifier and a conceptual component, which he called the signified. This conceptual component, the signified, is not a material object, but the thought, the idea of an object, it is what is called to mind when an individual hears or uses the appropriate signifier. In the case of the spoken language a signifier is any meaningful sound which is made, in the case of the written language a signifier is any meaningful mark written down, in 
the case of the media a signifier is any image which is relayed to the audience. Signifiers and signified can be separated in this way by semiologists; in the encounter of signs in everyday life however they constitute a whole: A single sign.

Saussure saw language as the premiere, but certainly not the only, sign system. Using language as a guide, there can be talked about the "languages" of such diverse things as fashion, and food preparation. There are such systems "codes." Within the semiotics literature, this notion of codes is a key part of the legacy of Saussure. In his work, Saussure saw codes as an interrelated set of signs that allow us to explain and understand our world. Those theorists and researchers who adhere to a Saussure an model of semiotics tend to call their form of inquiry "semiology" (Melahat Arıkl1, 2016).

\section{Lotman semiotic theory}

Culture is first and foremost a semiotic system. One of the earlier definitions of a semiotic system can be found in Lotman's article in which he defines a system as a "structure of elements and of rules for combining them that is in a state of fixed analogy to the entire sphere of an object of knowledge, insight and regulation". This definition may seem rather hermetic, but it points out the main features of a system: it is a structure of discernable elements with certain functions Structure in its turn is a set of elements organized in a certain hierarchy and with certain purpose, which makes this system distinct and different from other systems and nonsystems. The crucial point is that a system is a construction, a methodological tool that is applied in the analysis. It is important to keep this definition in mind because Soviet semioticians and structuralists in general have often been criticized that in their writings it is not always possible to distinguish whether the term "system" is used as a working concept for description of certain phenomena or as an ontological category, when some specific "laws" of the system are "discovered" as an objective fact. In this book, I stick to the understanding of system as first and foremost an abstraction, a methodological construct that is used to describe the products of thinking activity of man such as language, literature, cinema, art, or culture in terms of periods, different and opposing tendencies, and other parameters as well as to analyze how we use and interact through them. Culture, language, or any other semiotic system can therefore be best compared with an interface or an operating system: they do not exist "on their own" but, on the contrary, entirely depend on their users who use, develop, change, or completely abandon them if necessary. The peculiarity of language and culture as a whole is that from an early age we absorb them as an indivisible part of our lives and rarely question how they operate, which becomes the focus of the majority of Lotman's semiotic works (Aleksei Semenenko, 2012).

A sign has a meaningful thing which is defined as meaning of something for other than itself. Signs are defined as physical form like sign vehicle; words, images, sounds, objects or acts. Goldsmith is explained interpretation of signs as having three levels; syntactic, semantic, pragmatic. The signs which are viewed in the media by the public can be constructed to form certain meanings, meanings which appear perhaps unconnected to the signs themselves. (Winfried Noth, 2006).

Semiology therefore provides the interpreter with a means of accessing how signs are deployed and understood within the media. It enables the interpretation of the underlying meanings within media output and how the audience accepts, rejects or redefines those meanings. It can be applied to anything which can be seen as signifying something; like to everything which has meaning within a culture. Semiotics can be analyzed to any media texts and to the practices involved in producing and interpreting such texts like televisions and radio programmes, films, cartoons, newspapers, posters and other ads. Semiotic objects have set of dynamic meanings that changing with time and culture.

\section{Semiotic research methodology}

Semiotic research methodology is a way to systematically solve the research problem. It may be understood as a science of studying how research is done scientifically. In it we study the various steps that are generally adopted by a researcher in studying his research problem along with the logic behind them. It is necessary for the researcher to know not only the research methods/techniques but also the methodology. Researchers not only need to know how to develop certain indices or tests, how to calculate the mean, the mode, the median or the standard deviation or chi-square, how to apply particular research techniques, but they also need to know which of these methods or techniques, are relevant and which are not, and what would they mean and indicate and why. Researchers also need to understand the assumptions underlying various techniques and they need to know the criteria by which they can decide that certain techniques and procedures will be applicable to certain problems 
and others will not. All this means that it is necessary for the researcher to design his methodology for his problem as the same may differ from problem to problem. Similarly, in research the scientist has to expose the research decisions to evaluation before they are implemented. He has to specify very clearly and precisely what decisions he selects and why he selects them so that they can be evaluated by others also. From what has been stated above, we can say that research methodology has many dimensions and research methods do constitute a part of the research methodology. The scope of research methodology is wider than that of research methods. Thus, when we talk of research methodology we not only talk of the research methods but also consider the logic behind the methods we use in the context of our research study and explain why we are using a particular method or technique and why we are not using others so that research results are capable of being evaluated either by the researcher himself or by others. Why a research study has been undertaken, how the research problem has been defined, in what way and why the hypothesis has been formulated, what data have been collected and what particular method has been adopted, why particular technique of analysing data has been used and a host of similar other questions are usually answered when we talk of research methodology concerning a research problem or study.

Semiotics is a methodology, because it can explain the genesis and the effectiveness of any kind of meaning that any social discourse attributes to any phenomenon. The genesis and effectiveness of a given signification are always problematic, so they need to be explained. All explanation imply the previous problematization of the signification of a phenomenon; the content of the explanation and the process of the problematization are subjective and ideological actions.

The research project ends with a paragraph about the intended scope of the work proposed. As to the hypotheses, this scope will be limited in this project to note that all the hypotheses of the research, the theoretical as the working ones and those related to methodology have been proved; or, if not, should be established that they have been falsified, and in which extent, and in this case they must be rejected. As to the consistency of the research project, the scope will depend on which hypothesis or hypotheses have been rejected. In addition, the conclusions can anticipate the transference that the research results are supposed to have, that is, what would be the social policy that in its corresponding area, can be adopted according to the research results, or what are the results that can be diffused academically or professionally, as supported by the performed research. So far, this is a basic outline of the steps leading to the building up of a research project using semiotic methodology. Each point creates doubts and gaps that have to be answered or filled and, even the mere fact of its enunciation, permits to disagree with the suggested content of such steps or stages and to pose others, more adequate to a semiotic research approach. This would be an overcoming of the methodology, in a specifically semiotic sense, which is the more desirable destiny of every theoretical or methodological proposal.

Certainly there is room for challenging 'traditional semiotics'. Semiotics has not become widely institutionalized as a formal academic discipline and it has not achieved the status of science which Saussure anticipated. There is little sense of a unified enterprise building on cumulative research findings. Sometimes semioticians present their analyses as if they were purely objective accounts rather than subjective interpretations. Few semioticians seem to feel much need to provide empirical evidence for particular interpretations, and much semiotic analysis is loosely impressionistic and highly unsystematic. Some seem to choose examples which illustrate the points they wish to make rather than applying semiotic analysis to an extensive random sample. Semiotic analysis requires a highly skilled analyst if it is not to leave readers feeling that it merely buries the obvious in obscurity. In some cases, it seems little more than an excuse for interpreters to display the appearance of mastery through the use of jargon which excludes most people from participation. In practice, semiotic analysis invariably consists of individual readings.

Semioticians do not always make explicit the limitations of their techniques, and semiotics is sometimes uncritically presented as a generalpurpose tool. A semiotic approach suits some purposes better than others and makes certain kinds of questions easier to ask than others. Signs in various media are not alike - different types may need to be studied in different ways. The empirical testing of semiotic claims requires a variety of methods. Structuralist semiotic analysis is just one of many techniques which may be used to explore sign practices. In relation to textual analysis, other approaches include critical discourse analysis and content analysis. Whereas semiotics is now closely associated with cultural studies, content analysis is well established within the mainstream tradition of social science research. Content analysis involves a quantitative approach to the analysis of the manifest 
content of texts, while semiotics seeks to analyze texts as structured wholes and investigates latent, connotative meanings. Semioticians have often rejected quantitative approaches: just because an item occurs frequently in a text or cultural practice does not make it significant. The structuralist semiotician is more concerned with the relation of elements to each other while a social semiotician would also emphasize the importance of the significance which readers attach to the signs within a text. Whereas content analysis focuses on explicit content and tends to suggest that this represents a single, fixed meaning, semiotic studies focus on the system of rules governing the discourse involved in texts and practices, stressing the role of semiotic context in shaping meaning (Daniel Chandler, 2002).

\section{Conclusion}

Semiotics is important because it can help not to take "reality" for granted as something having a purely objective existence which is independent of human interpretation. It teaches that reality is a system of signs. Studying semiotics can assist to become more aware of reality as a construction and of the roles played by ourselves and others in constructing it. It can help us to realize that information or meaning is not "contained" in the world or in books, computers or audio-visual media. Meaning is not 'transmitted' to people-people actively create it according to a complex interplay of codes or conventions of which people are normally unaware. Becoming aware of such codes is both inherently fascinating and intellectually empowering. People learn from semiotics that people live in a world of signs and have no way of understanding anything except through signs and the codes into which they are organized. Through the study of semiotics people become aware that these signs and codes are normally transparent and disguise people task in reading them. Living in a world of increasingly visual signs, people need to learn that even the most realistic signs are not what they appear to be. By making more explicit, the codes by which signs are interpreted people may perform the valuable semiotic function of denaturalizing signs. In defining realities, signs serve ideological functions. Deconstructing and contesting the realities of signs can reveal whose realities are privileged and whose are suppressed. The study of signs is the study of the construction and maintenance of reality. To decline such a study is to leave to others the control of the world of meanings, which people inhabit. Semiotics of culture is a research field within semiotics that attempts to define culture from semiotic perspective and as a type of human symbolic activity, creation of signs and a way of giving meaning to everything around.

\section{References}

Aleksei Semenenko, (2012). The texture of culture an introduction to Yuri Lotman's semiotic Theory. Palgrave macmillan. New York. p 22

Chandler, D, (2002). Semiotics: the Basics. London: Routlege. p.32

Daniel Chandler, (2002). SEMIOTICS THE BASICS. Routledge. New York, p. 326

Eero Tarasti, (2004). From nature to psyche. Printed by Hakapiano, Helsinki. pp 192

Eero Tarasti, (2009). Communication understanding. Printed by Greif, Tartu, pp 1293

Electronic resource. http://visual-memory.co.uk/daniel/Documents/S4B/sem01.html.

Electronic resource// http://visual-memory.co.uk/daniel/Documents/S4B/sem01.html

Melahat Arıkl1, (2016). Science of Semiology: Apply to an Event. International Review of Management and Marketing, 6(4), p 1074-1079.

Melahat Arıkl1, (2016). Science of Semiology: Apply to an Event. International Review of Management and Marketing, 6(4), p 1076.

Melahat Arrklı., (2016). Science of Semiology: Apply to an Event. International Review of Management and Marketing, 6(4), p 1075.

NellyShafik Ramzy, (2014). Visual language in mamluk architecture: A semiotic analysis of the Funerary Complex of Sultan Qaitbay in Cairo. Frontiers of Architectural Research, September, p 338-353

Peirce, C. S, (1960). Collected papers of Charles Sanders Peirce. Volume II. Cambridge: Harvard University Press. p.28

Peirce, C. S, (1998). The Essential Peirce: Selected Philosophical Writings, vol. 2. Bloomington. IN: Indiana University Press. p 412

Shirong Zhang, Fan Yang, (2012). The Semiotic Analysis on the Appearance of Chinese and American Pavilions in Shanghai Expo. 145 Journal of Language Teaching and Research, Vol. 3, No 1, pp. 141-146, January (CACADEMY PUBLISHER Manufactured in Finland.

Winfried Noth, (2006). Semiotica. Walter de Gruyter. 161-1. pp 249-263 